\section{The role of trait emotional intelligence in predicting networking behavior}

\author{
Teresa Torres-Coronas \\ María-Arántzazu Vidal-Blasco \\ Universitat Rovira i Virgili, Business Department, Tarragona, Spain
}

\begin{abstract}
Purpose - The purpose of this paper is to obtain evidence of the relation between entrepreneur proactive networking behavior and trait emotional intelligence to support transition towards entrepreneurial careers.
\end{abstract}

Design/methodology/approach - The Trait Emotional Intelligence Questionnaire-Short form (TEIQue-SF), developed by Petrides (2001, 2009), was used to test hypotheses on the factors that define a proactive use of a professional network and their relationship with the individual level of trait emotional intelligence and its four components (wellbeing, self-control, emotionality and sociability). A questionnaire was sent to local entrepreneurs to verify whether trait emotional intelligence acts as a predictor of proactive networking behavior.

Findings - Final findings partially confirm the research hypothesis, with some components of EI (well-being and sociability factors) showing a significant positive correlation with proactive networking behavior. This indicates that entrepreneurs' ability to regulate emotions influences their networking behavior helping them to succeed in their business relationships.

Originality/value - The present study provides a clear direction for further research by focusing on how trait emotional intelligence affects social networking behavior amongst entrepreneurs, thus demonstrating the utility of using trait EI to evaluate high potential entrepreneurs.

Keywords - Emotional intelligence, entrepreneurship, networking behavior, TEIQue, proactive behavior.
Received on

03/31/2016

Approved on

10/06/2016

\section{Responsible editor:}

Prof. Dr. João Maurício Gama

Boaventura

\section{Evaluation process: \\ Double Blind Review}

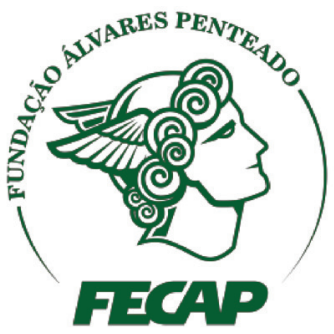

Review of Business

Management

DOI: $10.7819 /$ rbgn.v0i0.3127 


\section{Introduction}

Brass, Galskiewicz, Greve and Tsai (2004) define a network as a set of actors and the set of ties representing some relationship, or lack thereof, between the actors. Social and professional networks have existed since society began. They provide spaces for people to interact and share personal and professional information and experiences. In face-to-face settings, networking spaces range from industry events to leisure activities. They both offer a chance to grow a social network in productive directions. With the development of the Internet, most professionals start to use sites such as Twitter or Facebook, for instance, to find professional opportunities. At the same time, those who want to connect with more business-related contacts turn to sites like LinkedIn to develop professional relationships. Notwithstanding the site type (personal versus professional or online versus offline) businessrelated purposes can be reached.

In the business world, a network usually involves contacts with a variety of colleagues for the purpose of mutual work benefits and they are important for accomplishing tasks and professional development (Linehan \& Scullion, 2008). Thus, professional networks include contacts in different categories: professionals of the same industry, professionals of other industries, suppliers, customers, financial institutions, governmental institutions, competitors and other companies' partners. These relationships take considerable effort and time to establish and sustain (Sowon, 2013); therefore, it is important to confirm which factors can have a positive and certain impact on successful networking strategies.

Entrepreneurship research has frequently examined the value of professional networks, and how such networks develop (Anderson, Dodd, \& Jack, 2008, 2010). Start-ups require a myriad of resources, from information to capital. For that reason, entrepreneurs form ties with outside entities to get access to critical resources. Such ties form the entrepreneur's "social capital", or the sum of the actual and potential resources embedded within, available through, and derived from a relationship network (Nahapiet \& Ghoshal, 1998). These networks give entrepreneurs access to other's information, advice, influence, and resources that are not available via market transactions (Hoang \& Antoncic, 2003; Ostgaard $\&$ Birley, 1994). It can also help the company to achieve economies of scale (Mancinelli \& Mazzanti, 2008). Thus, managerial implications relate to the fact that networking is a key asset for the competitive advantage of a company, business survival, growth and return on equity (Mitrega, Forkmann, Ramos, \& Henneberg, 2012; Watson, 2007). Despite this evidence, some findings indicate that the business advantages of networking are still undervalued (Bennett, Owers, Pitt, \& Tucker 2010) and that, sometimes, networking does not lead to anticipated outcomes as relationship might fail to develop (Sowon, 2013).

Given that entrepreneurial behavior is a function of individual differences, personality and ability factors should predict entrepreneurial activity and success (Zhao \& Seibert, 2006). In parallel, researchers study the role of networking in supporting entrepreneurial success (Lechner, Dowling, \& Welpe, 2006). But, what does networking behavior explain? Authors such as Treadway, Breland, Adams, Duke and Williams (2010) suggest that socioeconomic and managerial status could explain an important part of the levels of networking behavior, but other factors also come into play, such as skill and motivation, which need to be considered, as they operate interactively and assess the interactive impact of political skill (the ability to interact effectively with others). In addition, their findings indicate that, in general, individuals with a high politicallyskill level would find networking behaviors less difficult and more rewarding.

Other authors found that networking behavior is influenced by personality dimensions (i.e., extraversion, agreeableness, openness to experience) (Muscanell \& Guadagno, 2012; Wolff \& Kim, 2012). While Correa, Hinsley and Gil de Zúniga (2010) correlate individuals' personality 
traits and emotional stability with the use of networks. Given the social nature of networking activities, trait EI (TEI), conceptualized as a collection of emotional dispositions and selfperceptions located at the lower stratums of existing personality hierarchies (Petrides et al., 2007), is an important factor for predicting networking behavior. As Chell and Baines (2000) demonstrate, the ability to effectively interact with other people is associated with a higher trait EI (Chell \& Baines, 2000). In a highly competitive economy, emotional and social intelligence lead to a shared vision and a dramatic increase in success, as illustrated by Boyatzis and Soler (2012). Moreover, successful entrepreneurs will be the ones who effectively manage their networks and build strong relationships (Bhattacharyya, 2010). Network's effectiveness increases when networking activities are planned (O’Donnell, 2004) or, in other words, when, entrepreneurs are proactive in networking.

To test the arguments presented above, an online survey was conducted to study the relation between entrepreneur's proactive networking behavior and Trait EI. The Trait Emotional Intelligence Questionnaire-Short form (TEIQueSF), developed by Petrides (2001, 2009), was used to test hypotheses on the factors that define a proactive use of a professional network and their relationship with the individual level of trait emotional intelligence and its four components (well-being, self-control, emotionality and sociability).

In this regard, the article answers two key research questions: 1 . How does trait emotional intelligence relate to the proactive networking behavior among entrepreneurs? 2. How can trait emotional intelligence act as a predictor of proactive networking behavior? To answer these questions the research methodology follows the fundamentals of trait EI theory, based on Petrides (2001) and Petrides, Furnham and Mavroveli (2007). As a contribution, the paper lead us to a better understanding of the role trait EI plays in an entrepreneur's network development process. A review of related studies is considered in section two. Section three presents the research methodology and study. And finally, findings, discussion and conclusion are presented.

\section{Proactive Networking and Emotional Intelligence}

\section{I Proactive networking behavior}

In 2007 the European UniversityEnterprise Cooperation Network (Luca \& David, 2007) investigated the way the three main stakeholders - academics, employers and graduates - view the training of entrepreneurial competences in practical placement. The three groups considered that the best achieved competences were the following: capacity to establish productive relationships, capacity to understand customers' needs and, ability to gain social capital-professional networking. Two out of three main competences are related to networking behavior. This means that this competence is a must-have for entrepreneurs.

Networking implies building personal and professional relationships to create a system of information, contact, and support that is crucial for personal and career success (Rasdi, Garavan, \& Ismail, 2011). It can be understood as 'individuals', the attempts to develop and maintain relationships with others who have the potential to assist them in their work or career' (Forret \& Dougherty, 2004, p. 420). It is a process of building up and maintaining informal, cooperative relationships in the expectation that this networking will assist job performance and career success (Van Emmerik, Euwema, Geschiere, \& Schouten, 2006). These definitions understand networking as a proactive behavior, which involves developmental relationships for professional success (Kram, 1985). In the same way, Sowon (2013) conceptualizes networking as a process that involves proactive behavior, where proactivity is needed in order to build useful relationships.

In the field of entrepreneurial research, the value of networks as part of the explanation for the 
entrepreneurial success is widely acknowledged (Bøllingtoft, 2012; Tipu \& Arain, 2011; Rothschild \& Darr, 2005; Hite \& Hesterly, 2001). According to Anderson et al. (2008, p. 125), networks "contribute to entrepreneurial capacity by extending the individual's asset base of human, social, market, financial and technical capacity". Formal and informal networks are crucial in an entrepreneurial environment (Rothschild \& Darr, 2005); though most entrepreneurs are not aware of the value of their networks for their business (De Klerk \& Saayman, 2012).

The level of proactivity that an entrepreneur adopts in networking can be positioned along a continuum from "reactive" to "proactive" (O’Donnell, 2004). As O’Donnell (2004, p. 212) states "an owner-manager will be "proactive" in networking with a particular network actor if he networks with the actor in a planned and deliberate way, has keen expectations of the benefits of networking and regularly creates opportunities to network with the actor." Networking with a view to developing strong ties requires a proactive behavior. Hulsink and Elfring (2007) examine how entrepreneurs shape their network of strong and weak ties to match a new venture's changing requirements over time.

In a parallel way, professional networking based on the Internet is helping increase the size of potential networks. Moreover, the structural characteristics of digital technology allow the establishment of numerous self-perpetuating connections (Kuss \& Griffiths, 2011). At this respect, professional networking on the Net is increasing to support professional network development. Thus, both virtual and face-to-face networks must be emphasized as key factors for a successful development of any entrepreneurial activity.

Proactive networking behavior concentrates on the use of strategies to implement networking activities. These include networking activities to align networking with business strategy and activities to build an effective on line and off-line network. These activities represent intentions on the part of the entrepreneur to manage his/her network in a systematic and professional way. It is also true that managers engage more in networking activities as the level of uncertainty perceived in the environment is increased (Sawyerr, McGee, \& Peterson, 2003). This is due to the fact that networking is derived from the firm's networking needs and its networking capabilities (Kaufmann \& Schwartz, 2008) and it is crucial that entrepreneurs "act strategically when investing time in their network to avoid resource deficits on the one hand and neglecting other important tasks on the other" (Semrau \& Werner, 2012, p. 174).

Nevertheless, despite the importance of networking as a strategy to organizations' evolution (Wolff \& Kim, 2012), 85\% of managers still do not use this activity with strategic purposes (Cheuk, 2007). As a consequence, it is more important than ever to understand the factors that can positively change that percentage despite that some authors, such as Wiklund, Patzelt and Shepherd (2009), argue that entrepreneurial resources, including social networks, only have indirect effects on venture growth.

\subsection{Trait EI as predictor of proactive networking behavior}

Several studies try to understand networking predictors and the establishment and usage of social networks among entrepreneurs (Jack \& Anderson, 2002; Slotte-Kock \& Coviello, 2010). Forret and Dougherty (2001) conducted a study to examine the relationship of personal and job characteristics to involvement in networking. Multiple regression results showed that gender, socioeconomic background, selfesteem, extroversion, favorable attitudes toward workplace politics, organizational level, and type of position were significant predictors of involvement in networking behaviors. These authors also found that individuals possessing certain "personality traits and attitudes might be more likely to engage in proactive behaviors thereby leading to interactions with others in their environment". (Forret \& Dougherty, 2001, 
p. 288). In a more recent research, Wolff and Kim (2012) offer an integrative framework on the personality-networking relationship.

When online networking is taken into consideration, literature suggests that extraversion, emotional stability, and openness to experience relate to uses of social applications on the Internet (Correa et al., 2010). Their study establishes the relationship between these three factors of personality and the use of social networking sites suggesting that while extroversion and openness to experiences are positively related to the use of social networking sites, emotional stability is negatively related to it (i.e. people with greater levels of neuroticism and negative affectivity are more likely to engage in these social activities). Moreover, they appreciated differences by gender and age. So, personality characteristics and emotional intelligence will also affect professional networking opportunities through non-business related networks.

Academic articles exploring the concept of EI began to appear in the early 1990s, when Salovey and Mayer (1990), defined EI is "a kind of social intelligence that enables individuals to monitor the emotions of others and their own emotional status" (p. 187). However, one the most important development in the EI literature is Petrides and Furnham's (2001) conceptual bifurcation resulting in two distinct perspectives on EI: ability EI and trait EI. Following Siegling, Saklofske and Petridres (2004) "the differentiation between trait EI and ability EI is predicated mainly on the method used to measure the construct and not on the elements (facets) that the various models are hypothesized to encompass. " (p. 382).

The ability EI perspective conceptualizes EI as a constellation of cognitive-emotional abilities located in extant frameworks of human intelligence (Petrides, 2011). It involves actual abilities and it measures with 'maximumperformance' tests, and it is directly applicable to cognitive ability (Petrides \& Furnham, 2001, p. 426). On the other hand, trait EI is defined as "a constellation of emotional self-perceptions located at the lower levels of personality hierarchies"
(Petrides et al., 2007). Trait EI is comprised of 'behavioral dispositions and self-perceived abilities' and should be measured through selfreport questionnaires. It is related to the study of personality (Petrides \& Furnham, 2001, p. 426). For entrepreneurs, "this ability to understand and accurately express nonverbal emotions as well as interpret the emotional expressions of others is extremely important" (Boren, 2010, p. 56). The awareness of nonverbal expressions, for example, helps entrepreneurs in relating to customers and employees alike and, the "regulation of emotions assists in maintaining calm in stressful situations" (Boren, 2010, p. 57).

The construct developed by Petrides and Furnham (2001), measured through the TEIQue questionnaire, consists of four factors:

a) well-being, related to optimism, selfesteem and trait happiness;

b) self-control, related to emotion regulation, impulsiveness and stress management;

c) emotionality, related to emotional expression, trait empathy, and quality of relationship; and

d) sociability, related to emotion management, assertiveness and social awareness.

For our study, we will be using Petrides and Furnham's (2001) trait EI definition and EI will be studied within a personality framework (Petrides, 2001; Petrides \& Furnham, 2001, 2006). Academic research has suggested that emotional intelligence is responsible for an individual's ability to engage in social interactions (Lopes, Salovey, \& Straus, 2003). These interactions help construct social skills (Fox \& Spector, 2000). This is an argument based on the hypothesis that emotions are key elements of how we communicate and socialize within groups (Lopes et al., 2004). So, social skills can be recognized as a means to facilitate communication and as an important aspect of effective team work through relationship bonding. In a similar way, emotional abilities also play an important role in promoting critical reflection (Clarke, 2010), work performance (Behbahani, 2011), and better quality of work performance (Khokhar \& Kush, 
2009). All of the above are skills an entrepreneur must have.

Trait EI is an important factor in the prediction of entrepreneurial outcomes (Ahmetoglu, Leutner, \& Chamorro, 2011; Chell, 2008) and entrepreneurial behavior (Bahadori, 2012) defined as a set of actions to exploit entrepreneurial opportunities. Given the social nature of entrepreneurial activities, trait EI can predict entrepreneurial success. Indeed, several authors suggest that higher levels of trait EI are necessary to exploit opportunities and innovations (Chell \& Baines, 2000). Therefore, there is a relationship between entrepreneurs' Trait EI and their success (Karimi, Kloshani, \& Bakhshizadeh, 2012). Based on these arguments, this study states the following two hypotheses:

H1: Trait EI has positive effect on proactive networking behavior.

H2: The four components of Trait EI (Well-being, Self-control, Emotionality and Sociability) have positive effect on proactive networking behavior.

\section{Research Method}

\section{I Sample}

Authors employed a structured questionnaire to collect detailed information about trait emotional intelligence and networking activities of local entrepreneurs residing in Tarragona ${ }^{1}$. The Spanish National Bureau of Statistics (http://www.ine.es) was used as the population frame for the surveys. In 2013, there were 27.635 owner-managed or start-up enterprises in Tarragona. In order to obtain convenient sample questionnaires were e-mailed to a stratified sample of 450 owner-managed firms. An online self-administered questionnaire was used to approach the sample. A total of 42 (9.3\%) usable questionnaires were received and used in the analysis. Among these, $16.6 \%$ were women and $83.3 \%$ were men. In terms of age, the results revealed that the majority of respondents $(66.6 \%)$ were below the age of 45 . It may be argued that this age reflects, to some extent, the maturity level of business entrepreneurs. Among respondents, $11.9 \%$ had more than 30 years of experience as entrepreneurs, $28.5 \%$ between 20 and 30 years, $50 \%$ between 10 and 20 , and only a $9.5 \%$ had less than 10 years of experience. A $35.7 \%$ of the respondents worked in the manufacturing sector, a $54.7 \%$ in the service sector and a $9.2 \%$ ) in the primary sector. Amongst the respondents, 30.9\% had never used networking proactively, 19\% used it on a daily basis, $30.9 \%$ less than once a month and $19 \%$, several times per month.

\section{$3 \cdot 2$ Instruments}

The instrument chosen to measure trait emotional intelligence in this study was the Trait Emotional Intelligence Questionnaire-Short Form (Petrides \& Furnham, 2006). It provides scores on four factors: well-being, self-control, emotionality, and sociability (Petrides, 2001) and explains criterion variance at a level comparable to that of the TEIQue full form (Siegling, Veseley, Petrides, \& Saklofkse, 2015).

A high well-being score indicates an overall sense of well-being. In general, individuals with high scores on this factor are fulfilled and satisfied with life. The self-control factor refers to one's degree of control over their urges and desires. Individuals with a high self-control score have the ability to manage and regulate external pressures. Individuals with a high emotionality score possess a wide array of emotion-related skills: recognizing internal emotions, perceiving emotions, and expressing emotions. The sociability factor focuses on one's social relationships and social influence. This factor differs from the emotionality factor in that it evaluates one's influence in a variety of social contexts, rather than just in personal relationships with family and friends. Individuals with a high sociability score are good listeners and effective communicators (Petrides, 2001).

The psychometric properties of the instrument are supported by Petrides (2009), Cooper and Petrides (2010), Perera (2015), Siegling et al. (2015), and the recent work of 
Andrei, Siegling, Aloe, Baldaro and Petrides (2016). For the present study, a reliability Alpha coefficient of 0.84 was obtained for the trait emotional intelligence scale and an alpha coefficient of 0.8 for the factor of Emotionality (8 items), 0.6 for Self-control (6 items), 0.82 for Well-being (6 items) and 0.67 for Sociability (6 items). The four remaining items contribute to the cumulative TEI score.

As networking is not a 'one-dimensional phenomenon' (Torenvlied, Akkerman, Meier, \& O'Toole, 2012), other variables have been included in the study. These added variable are related to the nature of the networking activity (strategic versus non-strategic) and to the way contacts are maintained (off-line versus on-line), which is a type of networking behavior (Forret $\&$ Dougherty, 2001).

Strategic versus non-strategic. This research assumes that, as any other managerial action, networking can be categorized as either strategic or non-strategic. A strategic networking must be understood as the process that entrepreneurs use to align networking activities with business strategy. All the constructs were assessed with selfreport measures. Responses to all items were made on 7-point Likert scales from strongly disagree (1) to strongly agree (7).

Online versus offline networking. As in today's digital society, social networking technology can facilitate communication and collaboration between a new venture as its stakeholders (clients, suppliers ...) two variables measuring how entrepreneurs built their networks were introduced in the analysis. Offline networking measures how entrepreneurs develop their professional network through the most appropriate offline channels (meetings, conferences,...) in terms of planned objectives and, online networking measures how entrepreneurs build their professional network through the most appropriate online channels (virtual communities) in terms of planned objectives. In both cases, there is an implicit proactive behavior to search for opportunities for both formal and informal interaction and collaboration with clients/customers and other stakeholders.
Control variables. Following previous research (i.e., Bahadori, 2012) this study includes age (years), gender (1 female, 2 male), and working experience as control variables. The length of professional experience is considered to be an influential factor in EI. Mayer, Caruso and Salovey (1999) asserted that in order for emotional intelligence to be considered a standard intelligence, it should increase with age and experience. Similarly, gender differences affect networking behavior and TEI. Though Forrett and Dougherty (2001) found little discrepancies in networking behavior between men and women, Van Emmerik et al. (2006) shows that men use their networking activities more effectively. Concerning TEI, Petrides and Furnham (2000, 2001) indicate that gender is a significant predictor of self-estimated TEI, with women scoring higher than men on the emotionality factor (Petrides $\&$ Furnham, 2000; Siegling, Sfeir, \& Smith, 2014). Other studies, such as the one of Mikolajczak, Menil and Luminet (2007), show men scoring higher in sociability and self-control and no differences on the well-being factor. Therefore, age, gender, and length of working experience as an entrepreneur were included in the analysis.

\section{$3 \cdot 3$ Data analysis}

Correlation coefficients and reliabilities are shown in Table 1, which presents the result obtained from a bi-variate analysis. The findings indicate that Proactive Networking Behavior was positive and moderately associated with Strategic Networking $(\mathrm{r}=.332)$, and it is highly correlated with Trait EI and two of its components (Wellbeing and Sociability), with their respective $r$ $(\mathrm{r}=.603, \mathrm{r}=.626, \mathrm{r}=.603)$. Finally Proactive Networking is negatively correlated with Gender $(\mathrm{r}=-.595)$. Previous research on proactivity has also revealed that proactivity is contingent on gender (Forret \& Dougherty, 2004).

Total Trait EI correlated highly with its four components, as expected, and moderately with Offline networking, Age and Years in the Labor Market $(r=.465, r=.675, r=.626)$. Trait EI Well-being correlated with Proactive 
Networking, Offline Networking and Gender $(\mathrm{r}=.626, \mathrm{r}=.675 ; \mathrm{r}=-.444)$. Trait EI Sociability correlated with Proactive Networking, Offline Networking, Gender, Age and Years in the Labor Market $(r=.607, r=.338 ; r=-.331, r=.714$, $\mathrm{r}=.619)$. Trait EI Self-control was positively correlated with Offline Networking, Gender, Age and Years in the Labor Market $(r=.338, r=.353$; $\mathrm{r}=.482, \mathrm{r}=545)$ and negative correlated with Strategic Networking $(r=-.333)$. Finally, Trait EI Emotionality correlated with Offline Networking, Age and Years in the Labor Market $(r=.498$, $r=.541 ; r=.516)$.

In this study, we formulated different hypotheses regarding the relationship between proactive networking and trait EI and its four dimensions. In the first hypothesis, it was hypothesized that: (a) trait EI would be positively related to proactive networking behavior. We found support to Hypothesis 1. In the Hypothesis 2, it was hypothesized that: (a) trait EI components would be positively related to proactive networking behavior. Support was found for two of the subscales, well-being and sociability. Thus, it can be pointed out that proactive networking behavior is not related to trait EI global scale, emotionality and self-control. This is surprising, as the ability to influence others should be expected to impact on proactive networking behavior.

Table 1

Pearson's correlations

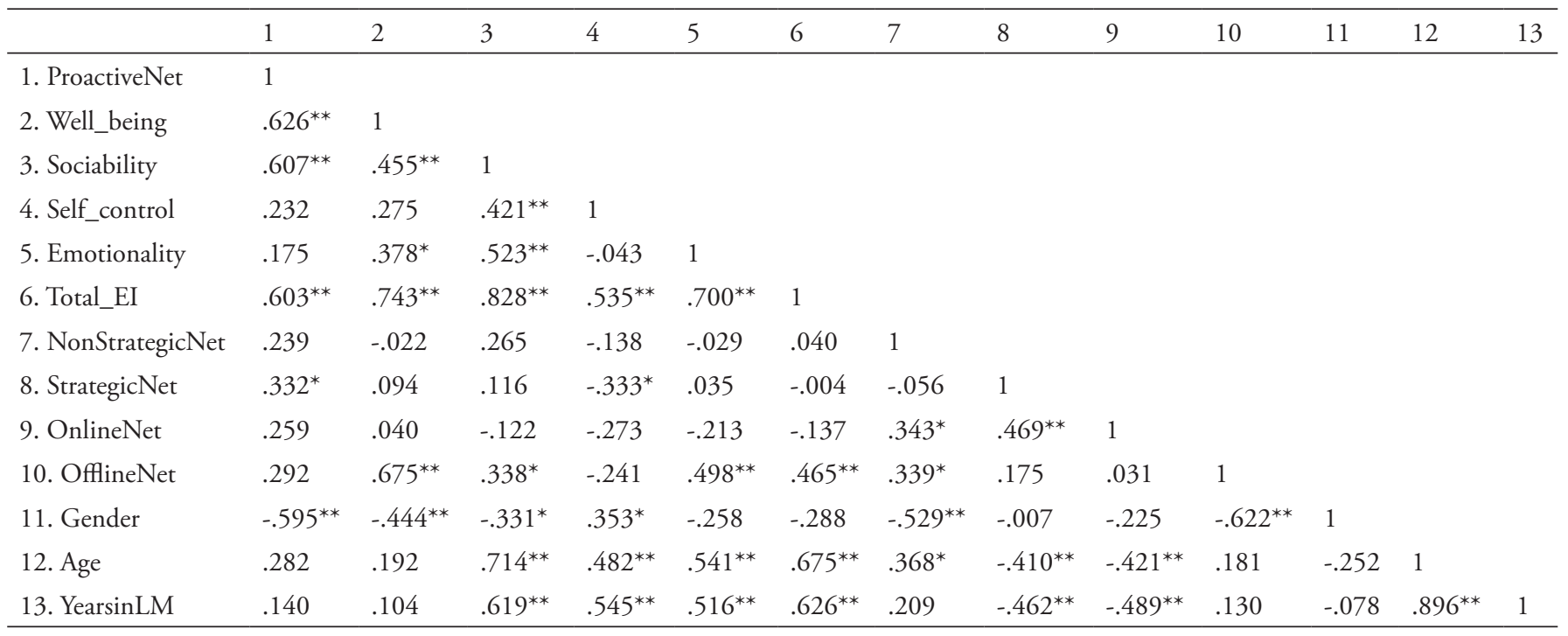

Note. $\mathrm{N}=42$. Gender coded (male=2, female $=1) .{ }^{* *} \mathrm{p}<.01{ }^{*} \mathrm{p}<.05$.

To test the impact of the explanatory variables on proactive networking behaviour, a multiple linear regression analysis was conducted. In particular, we adjust to the explained variable (ProactiveNet) a linear equation with ordinary least squares using the SPSS software. The explanatory variables are the four dimensions of EI (Well-being, Sociability, Self-control and Emotionality), StrategicNet, OnlineNet, OfflineNet and the control variables Gender, Age and YearsinLM. This regression will allow us to determine if all of the IE components are relevant to explain proactive net behavior or, on the contrary, only some of them. Given that, unfortunately, the sample is not very large but the potential set of explanatory variables is great, to adjust linear regressions we implement them with stepwise method by using forward selection. It involves starting with no variables in the model, testing the addition of each variable using a chosen model comparison criterion, adding the variable (if any) that improves the model the most, and 
repeating this process until none improves the model. In order to choose the variables to include that, we use the $F$-to-enter threshold criteria. Results are presented in Table 2.

Table 2 only shows the variables that we found to be relevant to explain ProactiveNet. $F$ statistic indicates that the model is significative with a p-value of practically 0 . Likewise, DurbinWatson statistic suggests that there is not a relevant problem of heterocedasticity. Regarding colinearity, we can observe that all the variables have a tolerance index above 0.4 , and the VIF is in all variables clearly below 10 and following
Belsley's criteria, condition index indicates no colinearity.

It can be observed that, Hypothesis 2 is partially confirmed since the relationship between Well-being and Sociability with ProactiveNet is positive and its significance is clearly above $99 \%$. On the other hand, Self-Control and Emotionality do not show explanatory power on ProactiveNet. Gender (being male) has a negative influence on ProactiveNet, and OfflineNet and OnlineNet are positively related to. Finally, YearsinLM is not recognized as explanatory variable in the model.

Table 2

Multiple regression analysis on Proactive Networking Behavior

\begin{tabular}{|c|c|c|c|c|c|c|c|}
\hline \multicolumn{8}{|c|}{ Coefficients $^{\mathrm{a}}$} \\
\hline \multirow{2}{*}{ Variables } & \multicolumn{2}{|c|}{ Non-standardized coefficients } & \multirow{2}{*}{$\begin{array}{c}\begin{array}{c}\text { Standardized } \\
\text {-coefficients }\end{array} \\
\text { value } \\
\end{array}$} & \multirow{2}{*}{ Student's t } & \multirow{2}{*}{ p-value } & \multicolumn{2}{|c|}{ Colinearity statistics } \\
\hline & Value & Estandar error & & & & Tolerance & VIF \\
\hline (Constante) & -.368 & 1.080 & & -.341 & .735 & & \\
\hline Well_being & .745 & .134 & .605 & 5.547 & .000 & .483 & 2.070 \\
\hline Sociability & .495 & .117 & .374 & 4.247 & .000 & .741 & 1.349 \\
\hline Gender & -1.514 & .301 & -.517 & -5.033 & .000 & .545 & 1.835 \\
\hline OfflineNet & .400 & .083 & .570 & 4.795 & .000 & .406 & 2.460 \\
\hline OnlineNet & .109 & .049 & .179 & 2.228 & .032 & .893 & 1.120 \\
\hline
\end{tabular}

Note. a. Dependent variable: ProactiveNet

The Condition Index of this model is 25,12 whereas Durbin-Watson statistic is 2.364 . The selected model presents and adjusted $R^{2}=76,50 \%$ and a $F$ statistic 27.625 which p-value is $0 \%$.

\section{Discussion}

Our research supports the idea that a combination of well-being and sociability is required to explain proactive networking behavior. These results are consistent with previous ones. Thus, for example, Forret and Dougherty (2001) found that engaging in networking behaviors might be viewed as highly threatening to low-self-esteem individuals or individuals with low score on Well-being. Low self-esteem individuals may feel they have nothing worth contributing to others and as a result may withdraw from networking opportunities. In contrast, individuals with higher self-esteem are expected to display more of a willingness to engage in networking behaviors as these individuals feel more confident when conducting networking activities. This idea is coherent with the notion that self-efficacy judgments can be used to explain why people develop an implicit interest in tasks, even tasks towards which they initially feel no intrinsic motivation (Bandura, 1977). One of these tasks is negotiation.

To Elfenbein, Foo, White, Tan and Aik (2007), negotiating skills are also crucial to entrepreneurial success. Entrepreneurs must negotiate with their suppliers, vendors, distributors and employees. The ability to recognize others' emotions is crucial and people higher on the ability to recognize others' emotions do better in 
buying-selling negotiations and establishing more effective entrepreneurial networks. At the same time, Trait EI is crucial in responses to pressure situations, such as negotiations, as demonstrated by Laborde, Lautenbach, Allen, Herbert and Achtzehn (2014).

As stated earlier, entrepreneurs' social networks can be made up of online as well as offline relationships. Entrepreneurs obtain resources from the social networks (Witt, 2010) and different social networks provide different resources to entrepreneurs (Jenssen \& Koenig 2002; Witt, 2010). It is the composition of their social networks that determines which resources entrepreneurs can obtain from it. Therefore, entrepreneurs must develop their professional network through the most appropriate offline and online channels. Moreover, in both cases there is an implicit proactive behavior, as confirmed by our results.

Relating to gender, few empirical studies exist that examine the gender differences in networking (Hanson \& Blake, 2009; Watson, 2011). Previous studies, such as Ibarra (1992), call for further empirical evidence to clarify how men's and women's networks differ, the extent of these differences and the potential consequences of any such differences. Cromie and Birley (1992) argue that because the majority of women enter self-employment from a non-managerial background, it is likely that their personal network contacts will not be as extensive or well-developed as their male counterparts. Though, even where women move directly from paid employment into self-employment, it is likely that they have fewer network contacts (Cromie \& Birley, 1992). In parallel, women might have less entrepreneurial self-efficacy (Wilson, Kickul, \& Marlino, 2007) and might feel a stronger need to develop a range of network ties from which they can access advice. Our results are consistent with these previous studies, as female entrepreneurs appear to be more involved in proactive networking than male entrepreneurs. This reality could be understood as a consequence of gender inequality in labor markets.
By incorporating the trait EI literature into entrepreneurial network research, we have attempted to contribute to entrepreneurship research by shedding light on what has been consistently identified as an under researched issue. The hypothesis tested can guide future empirical investigations into the critical role Trait EI plays in an entrepreneurs network development process.

\section{Limitations and Future Research}

This study has some limitations but it also opens up the door to new research studies. As previously discussed, one important limitation of this research is the final sample size. So, in order to increase the reliability and consistency of the results, the study should be replicated to achieve significant changes in sample size.

Other variables, such as the size of the network and the strength of interpersonal ties, should be taken into consideration in the analysis and incorporated in the model. These variables should be included as a way to measure social networks. Following Anderson et al. (2008) definition, the size of the network, which is a crucial strategic asset, affects the number of contacts that give a professional relevant information and knowledge. In a parallel way, the strength of ties in an entrepreneur's network influences entrepreneurs' economic outcomes (Berrou \& Combarnous, 2012). In consequence, further research should examine whether these two variables are correlated with EI and whether EI can be used a predictor of high potential networking behavior. In their research, Dries and Pepermans (2007) have demonstrated the utility of using some indication of emotional intelligence to identify high potential managers. Using Bar-On model (Bar-On, 1997), these authors demonstrate that EI subscales (assertiveness, independence, optimism, flexibility and social responsibility) appear to be "covert" high-potential identification criteria, separating between high potentials and regular managers. Furthermore, high potentials display higher levels of job performance. In a 
parallel way, it should be analyzed whether EI can be an identification criterion, separating between high potential network-building entrepreneurs and regular ones.

It is also important to find further evidence about the relationship between entrepreneurship and trait EI. Zampetakis, Kafetsios, Bouranta, Dewitt and Moustakis (2009), for example, to propose and empirically test a theoretical model positing relationships among emotional intelligence, creativity, proactivity, and attitudes towards entrepreneurship and entrepreneurial intent. Zampetakis et al. (2009) finds that EI is positively related to entrepreneurial intentions and provide the literature with another important piece of the puzzle concerning entrepreneurial motivation. In a similar way, Ahmetoglu et al. (2011) and Ghorbani, Johari and Moghadam (2012) study EI as a predictor of entrepreneurship but with contradictory results.

Other studies have found that there are basic differences in the structures of men's and women's networks which influence their effectiveness. Women tend to establish networks which are smaller in size, have stronger tie strength and a higher degree of similarity among members than men (Knouse \& Webb, 2001). Men's networks, which typically have weak ties and a broad or more diverse range in membership, tend to provide more instrumental benefits (Ibarra, 1997). Consequently, questions should be raised as to whether men and women entrepreneurs benefit equally from proactive networking. Research studies with a gender perspective should consider further exploring the level of EI of the entrepreneurs, the existence of gender differences and the growth and success of the new ventures. The research conducted by Khatoon (2013) should be replicated with larger samples to increase results' reliability.

As the significance of Internet-based technologies has triggered a technological and societal development that is irresistible, "e-entrepreneurship can be expected to gain further importance in the future" (Kollmann,
2009 , p. 13). In the context of a global economic crisis, the Internet is a platform for setting up business providing entrepreneurial opportunities to those who may not be capitally rich (Waddell, Singh \& Musa, 2006). Advances in ICTs and the advent of the Internet have facilitated the emergence and growth of collaborative strategies amongst small e-businesses (Matlay \& Martin, 2009; Matlay \& Westhead, 2005) which could be defined as low-cost strategies. In this context, further research should be directed towards analyzing proactive networking behavior of the so-called e-entrepreneurs and whether EI could play a different role in this new business world.

It is also clear that to broaden our understanding about networking behavior, quantitative and qualitative studies should coexist to provide in-depth detail about social and professional relationships dynamics. Conducting case studies, focus groups or interviews with entrepreneurs will help understand how entrepreneurs use social networks in their professional life. Thus, for example, the study of Zhang (2010), based of field interviews, offers a complete understanding of entrepreneurs' network behavior and its influence on the entrepreneurial process. In a similar way, Lockett, Jack and Larty (2012) presents findings from 14 in-depth interviews looking into the motivations and challenges of intermediaries and entrepreneurs engaged in the formation of a networking group. With no doubt, qualitative techniques are suitable to explore the softer side of networks and network behavior. For that reason, conducting qualitative studies would improve research outcomes on networking behavior among entrepreneurs.

\section{Conclusions}

Networking is a must-do activity for entrepreneurs as professional contacts link entrepreneurs with critical opportunities, support and resources. Networking helps an entrepreneur build more effective relationships with customers, suppliers, investors, public administration or financial institutions. As such, developing 
contacts through networking is important for starting a business and for its survival, growth and future development. In consequence, it is essential to investigate entrepreneurial behavior in terms of networking practices and predictors. To provide insights into this field of knowledge, this research evaluates how trait emotional intelligence supports proactive networking behavior amongst entrepreneurs, thus demonstrating the utility of using trait EI to evaluate high potential entrepreneurs. It explores whether trait EI can be a good predictor of proactive networking behavior.

Final findings partially confirm the researched hypothesis, with some components of trait EI (well-being and sociability factors) showing a significant positive correlation with proactive networking behavior. Managerial implications of our findings relate to the fact that two dimensions of trait emotional intelligence (well-being, sociability) have positive effect on proactive networking behavior among entrepreneurs. This might indicate that entrepreneurs with higher scores in these components will proactively manage their networks. We have also suggested various future research avenues that will lead to a better understanding of the role trait EI plays in an entrepreneur's network development process.

\section{Nota}

1 Tarragona is a city located in the south of Catalonia on the northeast of Spain, by the Mediterranean sea. It is one of the provinces that make up the Autonomous Catalan Region.

\section{References}

Ahmetoglu, G., Leutner, F., \& Chamorro, T. (2011). EQ-nomics: Understanding the relationship between individual differences in Trait Emotional Intelligence and entrepreneurship. Personality and Individual Differences, 51(8), 1028-1033. doi: http://dx.doi.org/10.1016/j. paid.2011.08.016

Anderson, A. R., Dodd, S. D., \& Jack, S. (2008). Change and the development of entrepreneurial networks over time: A processual perspective. Entrepreneurship \& Regional Development, 20(2), 125-159.

Anderson, A. R., Dodd, S. D., \& Jack, S. (2010). Network practices and entrepreneurial growth. Scandinavian Journal of Management, 26(2), 121-133.

Andrei, F., Siegling, A. B., Aloe, A. M., Baldaro, B., \& Petrides, K. V. (2016). The incremental validity of the Trait Emotional Intelligence Questionnaire (TEIQue): A systematic review and meta-analysis. Journal of Personality Assessment, 98(3), 261-276. doi: http://dx.doi.org/10.1080 /00223891.2015.1084630

Bahadori, M. (2012). The effect of emotional intelligence on entrepreneurial behavior: A case studying a medical science university. Asian Journal of Business Management, 4(1), 81-85.

Bandura, A., (1977). Self-efficacy: Toward a unifying theory of behavioral change. Psychological Review, 84(2), 191-215.

Bar-On, R. (1997). Emotional quotient inventory: Technical manual. Toronto, ON: Multi-Health Systems.

Behbahani, A. (2011). A comparative study of the relation between emotional intelligence and employee's performance. Procedia -Social and Behavioral Sciences, 30, 386-389.

Bennett, J., Owers, M., Pitt, M., \& Tucker, M. (2010). Workplace impact of social networking. Property Management, 28(3), 138-148.

Berrou, J. P., \& Combarnous, F. (2012). The personal networks of entrepreneurs in an informal African urban economy: Does the 'strength of ties' matter? Review of Social Economy, 70(1), 1-30.

Bhattacharyya, A. (2010). The networking entrepreneur. The Journal of Entrepreneurship, 19(2), 209-221. doi: http://dx.doi. org/10.1177/097135571001900207 
Bøllingtoft, A. (2012). The bottom-up business incubator: Leverage to networking and cooperation practices in a self-generated, entrepreneurialenabled environment. Technovation, 32(5), 304-315. doi: http://dx.doi.org/10.1016/j. technovation.2011.11.005

Boren, A. (2010). Emotional Intelligence: The secret of successful entrepreneurship? Faculty Publications: Agricultural Leadership, Education \& Communication Department, 55(2), 53-61.

Boyatzis, R., \& Soler, C. (2012). Vision, leadership and emotional intelligence transforming family business. Journal of Family Business Management, 2(1), 23-30. doi: http://dx.doi. org/10.1108/20436231211216394

Brass, D. J., Galaskiewicz, J., Greve, H., \& Tsai, W. (2004). Taking stock of networks and organizations: A multilevel perspective. Academy of Management Journal, 47(6), 795-817.

Chell, E. (2008). The entrepreneurial personality: $A$ social construction (2nd ed.). East Sussex, England: Routledge.

Chell, E., \& Baines, S. (2000). Networking, entrepreneurship and microbusiness behavior. Entrepreneurship and Regional Development, 12(3), 195-215. doi: http://dx.doi. org/10.1080/089856200413464

Cheuk, B. (2007). Social networking analysis: Its application to facilitate knowledge transfer. Business Information Review, 24(3), 170-176.

Clarke, N. (2010). Emotional intelligence and learning in teams. Journal of Workplace Learning, 22(3), 125-145. doi: http://dx.doi. org/10.1108/13665621011028594

Cooper, A., \& Petrides, K. V. (2010). A psychometric analysis of the Trait Emotional Intelligence Questionnaire-Short Form (TEIQueSF) using Item Response Theory. Journal of Personality Assessment, 92(5), 449-457. doi: http:// dx.doi.org/10.1080/00223891.2010.497426
Correa, T., Hinsley, A. W., \& Gil de Zúñiga, H. (2010). Who interacts on the Web? The intersection of users' personality and social media use. Computers in Human Behavior, 26(2), 247-253. doi: http://dx.doi.org/10.1016/j. chb.2009.09.003

Cromie, S., \& Birley, S. (1992). Networking by female business owners in Northern Ireland. Journal of Business Venturing, 7(3), 237-251.

De Klerk, S., \& Saayman, M. (2012). Networking as key factor in Artpreneurial success. European Business Review, 24(5), 382-399. doi: http://dx.doi. org/10.1108/09555341211254490

Dries, N., \& Pepermans, R. (2007). Using emotional intelligence to identify high potential: A metacompetency perspective. Leadership \& Organization Development Journal, 28(8), 749-770. doi: http://dx.doi.org/10.1108/01437730710835470

Elfenbein, H. A., Foo, M. D., White, J., Tan, H. H., \& Aik, V. C. (2007). Reading your counterpart: The benefit of emotion recognition accuracy for effectiveness in negotiation. Journal of Nonverbal Behavior, 31(4), 205-223. doi: http:// dx.doi.org/10.1007/s10919-007-0033-7

Forret, M. L., \& Dougherty, T. W. (2001). Correlates of networking behavior for managerial and professional employees. Group and Organization Management, 26(3), 283-311. doi: http://dx.doi.org/10.1177/1059601101263004

Forret, M. L. \& Dougherty, T. W. (2004). Networking behaviors and career outcomes: Differences for men and women? Journal of Organizational Behavior, 25(3), 419-437. doi: http://dx.doi.org/10.1002/job.253

Fox, S., \& Spector, P. E. (2000). Relations of emotional intelligence, practical intelligence, general intelligence, and trait affectivity with interview outcomes: it's not all just ' $G$ '. Journal of Organizational Behavior, 21(2), 203-220. doi: http://dx.doi.org/10.1002/ 
(SICI) 1099-1379(200003)21:2<203::AIDJOB38>3.0.CO;2-Z

Ghorbani, M., Johari, S., \& Moghadam, A. (2012). Analysis of the relationship between emotional intelligence and entrepreneurship. Middle-East Journal of Scientific Research, 11(5), 679-689.

Hanson, S., \& Blake, M. (2009). Gender and entrepreneurial networks. Regional Studies, 43(1), 135-149. doi: http://dx.doi. org/10.1080/00343400802251452

Hite, J. M., \& Hesterly, W. S. (2001). The evolution of firm networks: From emergence to early growth of the firm. Strategic Management Journal, 22(3), 275-286.

Hoang H., \& Antoncic, B. (2003). Networkbased research in entrepreneurship. Journal of Business Venturing, 18(2), 165-187. doi: http:// dx.doi.org/10.1016/S0883-9026(02)00081-2

Hulsink, W., \& Elfring, T. (2007). Networking by entrepreneurs: Patterns of tie formation in emerging organizations. Organization Studies, 28(12), 1849-1872. doi: http://dx.doi. org/10.1177/0170840607078719

Ibarra, H. (1992). Homophily and differential returns: Sex differences in network structure and access in an advertising firm. Administrative Science Quarterly, 37(3), 422-447. doi: http:// dx.doi.org/10.2307/2393451

Ibarra, H. (1997). Paving an alternative route: gender differences in managerial networks. Social Psychology Quarterly, 60(1), 91-102. doi: http:// dx.doi.org/10.2307/2787014

Jack, S. L., \& Anderson, A. R. (2002). The effects of embeddedness on the entrepreneurial process. Journal of Business Venturing, 17(5), 467-487. doi: http://dx.doi.org/10.2307/2787014

Jenssen, J. I., \& Koenig, H. F. (2002). The effect of social networks on resource access and business start-ups. European Planning
Studies, 1O(8), 1039-1046. doi: http://dx.doi. org/10.1080/0965431022000031301

Karimi, P., Kloshani, M., \& Bakhshizadeh, A. (2012). A comparative study on emotional intelligence and cognitive between successful and unsuccessful entrepreneurs. Management Science Letters, 2(6), 2071-2076. doi: http://dx.doi. org/10.5267/j.msl.2012.06.013

Kaufmann, D., \& Schwartz, D. (2008). Networking strategies of young biotechnology firms in Israel. Annals of Regional Science, 43(3), 599-613. doi: http://dx.doi.org/10.1007/ s00168-008-0253-8

Khatoon, N. (2013). The impact of emotional intelligence on the growth of entrepreneurship. International Journal of Business Management and Research, 3(3), 1-8.

Khokhar, C. P., \& Kush, T. (2009). Emotional intelligence and work performance among executives. Europe's Journal of Psychology, 5(1), 1-11. doi: http://dx.doi.org/10.5964/ejop.v5i1.281

Knouse, S. B., \& Webb, S. C. (2001). Virtual networking for women and minorities. Career Development International, 6(4), 226-228.

Kollmann, T. (2009). E-entreprenuership: The principles of founding electronic ventures. Selected readings on information technology and business systems management. Hershey, PA: IGI Global.

Kram, K. E. (1985). Mentoring at work: Developmental relationships in organizational life. Glenview, IL: Scott, Foresman.

Kuss, D. J., \& Griffiths, M. D. (2011). Online social networking and addiction. A Review of the psychological literature. International Journal of Environmental Research and Public Health, 8(9), 3528-3552. doi: http://dx.doi.org/10.3390/ ijerph8093528

Laborde, S., Lautenbach, F., Allen, M. S., Herbert, C., \& Achtzehn, S. (2014). The role of 
trait emotional intelligence in emotion regulation and performance under pressure. Personality and Individual Differences, 57, 43-47. doi: http://dx.doi. org/10.1016/j.paid.2013.09.013

Lechner, C., Dowling, M., \& Welpe, I. (2006). Firm networks and firm development: The role of the relational mix. Journal of Business Venturing, 21(4), 514-540. doi: http://dx.doi.org/10.1016/j. jbusvent.2005.02.004

Linehan, M., \& Scullion, H. (2008). The development of female global managers: The role of mentoring and networking. Journal of Business Ethics, 83(1), 29-40. doi: http://dx.doi. org/10.1007/s10551-007-9657-0

Lockett, N., Jack, S., \& Larty, J. (2012). Motivations and challenges of network formation: Entrepreneur and intermediary perspectives. International Small Business Journal, 31(8), 866-889. doi: http://dx.doi.org/ $10.1177 / 0266242612448383$

Lopes, P. N., Brackett, M. A., Nezlek, J. B., Schutz, A., Sellin, I., \& Salovey, P. (2004). Emotional intelligence and social interaction. Personality and Social Psychology Bulletin, 30(8), 1018-1034. doi: http://dx.doi.org/ 10.1177/0146167204264762

Lopes, P. N., Salovey, P., \& Straus, R. (2003). Emotional intelligence, personality and the perceived quality of social relationships. Personality and Individual Differences, 35(3), 641-658.

Luca, M. R., \& David, L. T. (2007). Tuning research on university-enterprise partnership in training entrepreneurship [Project EUE-NET]. European University-Enterprise Cooperation Network, Brussels.

Mancinelli, S., \& Mazzanti, M. (2008). Innovation, networking and complementarity: Evidence on SME performances for a local economic system in North-Eastern Italy. Annals of Regional Science, 43(3), 567-597. doi: http:// dx.doi.org/ 10.1007/s00168-008-0255-6
Matlay, H., \& Martin, L. (2009). Collaborative and competitive strategies in virtual teams of e-entrepreneurs: A pan-European perspective. Australasian Journal of Information Systems, 16(1), 99-115. doi: http://dx.doi.org/10.3127/ajis.v16i1.560

Matlay, H., \& Westhead, P. (2005). Virtual teams and the rise of e-entrepreneurship in Europe. International Small Business Journal, 12(4), 279300 .

Mayer, J. D., Caruso, D. R., \& Salovey, P. (1999). Emotional intelligence meets traditional standards for an intelligence. Intelligence, 27(4), 267-298.

Mikolajczak, M., Menil, C., \& Luminet, O. (2007). Explaining the protective effect of trait emotional intelligence regarding occupational stress: Exploration of emotional labor processes. Journal of Research in Personality, 41(5), 11071117. doi: http://dx.doi.org/10.1016/j.jrp.2007.01.003

Mitrega, M., Forkmann, S., Ramos, C., \& Henneberg, S. C. (2012). Networking capability in business relationships: Concept and scale development. Industrial Marketing Management, 41(5), 739-751. doi: http://dx.doi.org/10.1016/j. indmarman.2012.06.002

Muscanell, N., \& Guadagno, R. (2012). Make new friends or keep the old: Gender and personality differences in social networking use. Computers in Human Behavior, 28(1), 107-112. doi: http://dx.doi.org/10.1016/j.chb.2011.08.016

Nahapiet, J., \& Ghoshal, S. (1998). Social capital, intellectual capital, and the organizational advantage. Academy of Management Review, 23(2), 242-266.

O'Donnell, A. (2004). The nature of networking in small firms. Qualitative Market Research: An International Journal, 7(3), 206-217. doi: http:// dx.doi.org/10.1108/13522750410540218

Ostgaard, T., \& Birley, S. (1994). Personal networks and firm competitive strategy - A 
strategic or coincidental match? Journal of Business Venturing, 9(4), 281-305. doi: http://dx.doi. org/10.1016/0883-9026(94)90009-4

Perera, H. N. (2015). The internal structure of responses to the Trait Emotional Intelligence Questionnaire-Short form: An exploratory structural equation modelling approach. Journal of Personality Assessment, 97(4), 411-423. doi: http:// dx.doi.org/10.1080/00223891.2015.1014042

Petrides, K. V. (2001). A psychometric investigation into the construct of emotional intelligence (Doctoral dissertation). University College London, London, England.

Petrides, K. V. (2009). Psychometric properties of the Trait Emotional Intelligence Questionnaire. In C. Stough, D. H. Saklofske, \& J. D. Parker (Eds.), Advances in the assessment of emotional intelligence (pp. 85-111). New York, NY: Springer.

Petrides, K. V. (2011). Ability and trait emotional intelligence. In T. Chamorro-Premuzic, A. Furnham, \& S. von Strumm (Eds.), The BlackwellWiley handbook of individual differences (pp. 656678). New York, NY: Wiley.

Petrides, K. V., \& Furnham, A. (2000). Gender differences in measured and self-estimated trait emotional intelligence. Sex Roles: A Journal of Research, 42(5), 449-461. doi: http://dx.doi. org/10.1023/A:1007006523133

Petrides, K. V., \& Furnham, A. (2001). Trait emotional intelligence. Psychometric investigation with reference to established trait taxonomies. European Journal of Personality, 15(6), 425-448. doi: http://dx.doi.org/10.1002/per.416

Petrides, K. V., \& Furnham, A. (2006). The role of trait emotional intelligence in a gender specific model of organizational variables. Journal of Applied Social Psychology, 36(2), 552569. doi: http://dx.doi.org/10.1111/j.00219029.2006.00019.x
Petrides, K. V., Furnham, A., \& Mavroveli, S. (2007). Trait emotional intelligence: Moving forward in the field of EI. In G. Matthews, M. Zeidner, \& R. Roberts, R. (Eds.), Emotional intelligence: Knowns and unknowns (pp. 151-166, Series in Affective Science). Oxford: Oxford University Press.

Petrides, K. V., Pita, R., Kokkinaki, F. (2007). The location of trait emotional intelligence in personality factor space. British Journal of Psycholoy, 98(2), 273-289. doi: http://dx.doi. org/10.1348/000712606X120618

Rasdi, R. M., Garavan, T. N., \& Ismail, M. (2011). Understanding proactive behaviours and career success: Evidence from an emerging economy. Organizations and Markets in Emerging Economies, 2(4), 53-71.

Rothschild, L., \& Darr, A. (2005). Technological incubators and the social construction of innovation networks: An Israeli case. Technovation, 25(1), 59-67. doi: http://dx.doi.org/10.1016/ S0166-4972(03)00064-6

Salovey, P., \& Mayer, J. D. (1990). Emotional intelligence. Imagination, Cognition and Personality, 9(3), 185-211.

Sawyerr, O. O., McGee, J., \& Peterson, M. (2003). Perceived uncertainty and firm performance in SMEs. The role of personal networking activities. International Small Business Journal, 21(3), 269-290. doi: http://dx.doi.org/ $10.1177 / 02662426030213002$

Semrau, T., \& Werner, A. (2012). The two sides of the story: Network investments and new venture creation. Journal of Small Business Management, 50(1), 159-180. doi: http://dx.doi. org/ 10.1111/j.1540-627X.2011.00348.x

Siegling, A. B, Saklofske, D. H., \& Petridres, K. V. (2004). Measures of ability and trait emotional intelligence. In G. J. Boyle, D. H. Saklofske, \& G. Matthews (Eds.), Measures of personality and 
social psychological constructs (pp. 381-414). San Diego: Academic Press.

Siegling, A. B., Sfeir, M., \& Smith, H. J. (2014). Measured and self-estimated trait emotional intelligence in a UK sample of managers. Personality and Individual Differences, 65, 59-64. doi: http://dx.doi.org/10.1016/j.paid.2014.01.027

Siegling, A. B., Veseley, A. K., Petrides, K. V., \& Saklofkse, D. H. (2015). Incremental validity of the Trait Emotional Intelligence QuestionnaireShort Form (TEIQue-SF). Journal of Personality Assessment, 97(5), 525-535. doi: http://dx.doi.or g/10.1080/00223891.2015.1013219

Slotte-Kock, S., \& Coviello, N. (2010). Entrepreneurship research on network processes: A review and ways forward. Entrepreneurship Theory and Practice, 34(1), 31-57. doi: http:// dx.doi.org/10.1111/j.1540-6520.2009.00311.x

Sowon, K. (2013). Networking enablers, constraints and dynamics: A qualitative analysis. Career Development International, 18(2), 120-138.

Tipu, S., \& Arain, F. (2011). Managing success factors in entrepreneurial ventures: A behavioral approach. International Journal of Entrepreneurial Behaviour and Research, 17(5), 534-560.

Torenvlied, R., Akkerman, A., Meier, K., \& O'Toole, L. (2012). The multiple dimensions of managerial networking. American review of public administration, 43(3), 251-272. doi: http:// dx.doi.org/ 10.1177/0275074012440497

Treadway, D., Breland, J., Adams, G., Duke, A., \& Williams, L. (2010). The interactive effects of political skill and future time perspective on career and community networking behavior. Social Networks, 32(2), 138-147. doi: http://dx.doi. org/10.1016/j.socnet.2009.09.004

Van Emmerik, I. J. H., Euwema, M. C., Geschiere, M., \& Schouten, M. F. A. G. (2006). Networking your way through the organization:
Gender differences in the relationship between network participation and career satisfaction. Women in Management Review, 21(1), 54-66.

Waddell, D., Singh, M., \& Musa, A. (2006). Entrepreneurship and innovations in e-business: An integrative perspective. Hershey, PA: IGI Global.

Watson, J. (2007). Modeling the relationship between networking and firm performance. Journal of Business Venturing, 22(6), 852-874. doi: http:// dx.doi.org/10.1016/j.jbusvent.2006.08.001

Watson, J. (2011). Networking: Gender differences and the association with firm performance. International Small Business Journal, 30(5), 536-558. doi: http://dx.doi. org/10.1177/0266242610384888

Wiklund J., Patzelt, H., \& Shepherd, D. (2009). Building an integrative model of small business growth. Small Business Economics, 32(4), 351-374. doi: http://dx.doi.org/10.1007/s11187-0079084-8

Wilson, F., Kickul, J., \& Marlino, D. (2007). Gender, entrepreneurial self-efficacy, and entrepreneurial career intentions: Implications for entrepreneurship education. Entrepreneurship: Theory and Practice, 31(3), 387-406.

Witt, P. (2010). Entrepreneurs' networks and the success of start-ups. Entrepreneurship \& Regional Development, 16(5), 391-412.

Wolff, H., \& Kim, S. (2012). The relationship between networking behaviours and the Big Five personality dimensions. Career Development International, 17(1), 43-66. doi: http://dx.doi. org/10.1108/13620431211201328

Zampetakis, L., Kafetsios, K., Bouranta, N., Dewitt, T., \& Moustakis, V. (2009). On the relationship between emotional intelligence and entrepreneurial attitudes and intentions. International Journal of Entrepreneurial Behaviour \& Research, 15(6), 595-618. doi: http://dx.doi. org/10.1108/13552550910995452 
Zhang, J. (2010). The problems of using social networks in entrepreneurial resource acquisition. International Small Business Journal, 28(4), 338-361. doi: http://dx.doi. org/10.1177/0266242610363524
Zhao, H., \& Seibert, S. E. (2006). The Big Five personality dimensions and entrepreneurial statuts. A meta-analytical review. Journal of Applied Psychology, 91(2), 259-271. doi: http:// dx.doi.org/10.1037/0021-9010.91.2.259

\section{About the authors:}

1. Teresa Torres-Coronas, $\mathrm{PhD}$ in Business Management, Universitat Rovira i Virgili, Spain.

E-mail: teresa.torres@urv.cat

2. María-Arántzazu Vidal-Blasco, PhD in Business Management, Universitat Rovira i Virgili, Spain.

E-mail: mariaarantzazu.vidal@urv.cat

\section{Contribution of each author:}

\begin{tabular}{lcc}
\hline Contribution & Teresa Torres-Coronas & María-Arántzazu Vidal-Blasco \\
\hline 1. Definition of research problem & $\sqrt{ }$ & $\sqrt{ }$ \\
2. Development of hypotheses or research questions (empirical & $\sqrt{ }$ & \\
studies) & $\sqrt{ }$ & $\sqrt{ }$ \\
3. Development of theoretical propositions & $\sqrt{ }$ & \\
(theoretical Work) & $\sqrt{ }$ & $\sqrt{ }$ \\
4. Theoretical foundation/ Literature review & & $\sqrt{ }$ \\
5. Definition of methodological procedures & $\sqrt{ }$ \\
6. Data collection & $\sqrt{ }$ \\
7. Statistical analysis & $\sqrt{ }$ & $\sqrt{ }$ \\
8. Analysis and interpretation of data & $\sqrt{ }$ \\
9. Critical revision of the manuscript & $\sqrt{ }$ \\
10. Manuscript Writing & & $\sqrt{ }$ \\
\hline
\end{tabular}

